\title{
Aerosol-Assisted Chemical Vapour Deposition of Lead Chalcogenide Thin Films from $\left[\mathbf{P b}\left(\left(\operatorname{SeP}^{\mathrm{i}} \mathbf{P r}_{2}\right)_{2} \mathbf{N}\right)\left(\mathbf{S}_{2} \mathrm{CNHexMe}\right)\right]$
}

\author{
Nathaniel Owusu Boadi (D), ${ }^{1}$ Selina Ama Saah $\left(\mathbb{D},{ }^{2}\right.$ Michael Baah Mensah $(\mathbb{D})$, \\ and Johannes A. M. Awudza $\mathbb{D}^{1}$ \\ ${ }^{1}$ Department of Chemistry, Kwame Nkrumah University of Science and Technology, Kumasi, Ghana \\ ${ }^{2}$ Department of Chemical Sciences, University of Energy and Natural Resources, Sunyani, Ghana \\ Correspondence should be addressed to Nathaniel Owusu Boadi; noboadi@gmail.com
}

Received 2 September 2020; Revised 2 November 2020; Accepted 6 November 2020; Published 17 November 2020

Academic Editor: Mingdong Dong

Copyright ( $\odot 2020$ Nathaniel Owusu Boadi et al. This is an open access article distributed under the Creative Commons Attribution License, which permits unrestricted use, distribution, and reproduction in any medium, provided the original work is properly cited.

In this study, $\left[\mathrm{Pb}\left(\left(\mathrm{SeP}^{\mathrm{i}} \mathrm{Pr}_{2}\right)_{2} \mathrm{~N}\right)\left(\mathrm{S}_{2} \mathrm{CNHexMe}\right)\right]$, a novel complex, was synthesised by refluxing $\left[\mathrm{Pb}\left(\mathrm{S}_{2} \mathrm{CNHexMe}\right)_{2}\right]$ and $\left[\mathrm{Pb}\left(\left(\mathrm{SeP}^{\mathrm{i}} \mathrm{Pr}_{2}\right)_{2} \mathrm{~N}\right)_{2}\right]$ complexes for 2 hours in chloroform and precipitating with methanol. The microelemental analysis, FT-IR, and NMR spectroscopies were performed on the complex and the melting point was determined. The crystal structure of this new compound has been determined. The structure showed a distorted square pyramidal geometry with 2 sulphur and 2 selenium atoms coordinating the central atom at the base of the pyramid and a lone pair occupying the axial position of the lead atom. The complex was used to deposit lead chalcogenide thin films by the aerosol-assisted chemical vapour deposition (AACVD) method at $300,350,400$, and $450^{\circ} \mathrm{C}$. The thin films matched with the powder X-ray diffraction (pXRD) pattern for cubic PbSe with a (200) preferred orientation at all the deposition temperatures. The scanning electron microscopy (SEM) and energy dispersive X-ray spectroscopy (EDAX) indicated that cubic PbSe crystals were formed.

\section{Introduction}

Lead chalcogenide nanocrystals and thin films have been studied widely for their applications in solar cells because of their large Bohr exciton radii (PbS $18 \mathrm{~nm}, \mathrm{PbSe} 47 \mathrm{~nm}$, and PbTe $46 \mathrm{~nm}$ ) [1-5].

When the nanocrystals have sizes that are about a tenth of the bulk material's Bohr exciton diameter, the electrons and holes can easily move within a thin organic film, which facilitates the transportation of charges between nanocrystals due to strong electronic coupling [4, 6-9]. To date, $\mathrm{PbSe}$ and $\mathrm{PbS}$ nanocrystals are being studied as potential Schottky solar cells $[10,11]$.

The nanocrystals of $\mathrm{PbSe}$ and $\mathrm{PbS}$ with similar bandgaps are reported to generate large open-circuit voltage and short-circuit current, respectively [12-16]. $\mathrm{PbS}_{x} \mathrm{Se}_{1-x}$ as a ternary alloy could potentially lead to better-engineered particles to optimize both voltage and carrier transport simultaneously [17].
Ternary lead sulphide selenide $\left(\mathrm{PbS}_{x} \mathrm{Se}_{1-x}\right)$ nanocrystals and thin films $[4,18-20]$ have not been studied extensively relative to $\mathrm{PbS}$ and $\mathrm{PbSe}$ [21-28]. Nanocrystalline semiconductor alloys give an alternative route to quantum confinement effects and bandgap tuning and thus produce new materials with unique properties $[29,30]$. The variable composition of alloys makes bandgap tuning possible while maintaining their size. The single-source precursor route to the synthesis of semiconducting nanoparticles and thin films is preferred over the dual and multisources because they are cleaner and less toxic and have the right stoichiometry because of the existing bonds in the single-source precursor $[1,28]$. In this work, $\left[\mathrm{Pb}\left(\left(\mathrm{SeP}^{\mathrm{i}} \mathrm{Pr}_{2}\right)_{2} \mathrm{~N}\right)\left(\mathrm{S}_{2} \mathrm{CNHexMe}\right)\right]$ complex was synthesised and characterized and used as a single-source precursor to deposit lead chalcogenide thin films using the aerosol-assisted chemical vapour deposition (AACVD) method. In the AACVD method, the precursor is dissolved in a suitable solvent and then carried as an aerosol by means of an ultrasonic humidifier with an inert carrier 
gas onto the substrate. The choice of solvent is critical for the aerosol formation, however, the precursor solution does not need to be volatile [31].

The AACVD method is simple and has many advantages such as the use of nonvolatile precursors, easy deposition of doped thin films, and easy control of precursor proportions when a mixture of precursors is deposited. It also eliminates issues such as blocking of carrier gas tubes, which occurs in atmospheric pressure chemical vapour deposition (APCVD) and other CVD techniques [31]. Figure 1 shows a schematic diagram of the AACVD setup.

\section{Materials and Methods}

All the chemicals used for the syntheses were procured from Sigma-Aldrich (U.K) and used as received. The synthesis of the $\mathrm{iPr} 2 \mathrm{P}(\mathrm{Se}) \mathrm{NHP}(\mathrm{Se}) \mathrm{iPr} 2$ ligand was done using the procedure reported by Cupertino et al. [32].

2.1. Instrumentation. A Flash 2000 Thermo Scientific elemental analyser was used for the microelemental analysis. A Stuart melting point apparatus (SMP 10) was used to determine the melting point. Mettler Toledo TGA/DSC analyser was used for the thermogravimetric analysis (TGA) under nitrogen from $30-600^{\circ} \mathrm{C}$ at a heating rate of $10^{\circ} \mathrm{C} \mathrm{min}^{-1}$. The powder $\mathrm{X}$-ray diffraction ( $\mathrm{pXRD}$ ) analysis was performed on a Bruker AXS D8 diffractometer with $\mathrm{Cu}-\mathrm{K} \alpha$ radiation $(\lambda=1.5418 \AA)$. The samples were scanned from $10^{\circ}$ to $85^{\circ}$ with a step size of $0.05^{\circ}$ and $5 \mathrm{~s}$ dwell time. The surface morphologies of the samples and elemental compositions were determined with the Philips (FEG) XL 30 SEM. A Bruker 400 NMR spectrometer was used for all NMR measurements.

2.2. Synthesis of $\left[\mathrm{Pb}\left((\mathrm{SePiPr} 2)_{2} \mathrm{~N}\right) 2\right]$ Complex. The $\left[\mathrm{Pb}\left(\left(\mathrm{SePiPr}_{2}\right)_{2} \mathrm{~N}\right)_{2}\right]$ complex was synthesised as described in our earlier report [24].

2.3. Synthesis of $[\mathrm{Pb}(\mathrm{S} 2 \mathrm{CNHexMe}) 2]$ Complex. In a typical synthesis, carbon disulphide $(1.32 \mathrm{ml}, 22 \mathrm{mmol})$ was added dropwise to a cold $\left(0^{\circ} \mathrm{C}\right)$ stirring solution of N-methyl-N-hexylamine $(6.64 \mathrm{ml}, 44 \mathrm{mmol})$ dissolved in methanol $(50 \mathrm{ml})$ and allowed continuous stirring for 30 minutes. Methanolic $\mathrm{Pb}$ $\left(\mathrm{CH}_{3} \mathrm{COO}^{-}\right)_{2}(2.09 \mathrm{~g}, 5.5 \mathrm{mmol}$ in $10 \mathrm{ml}$ methanol) was poured dropwise into the yellow solution and stirred for further 30 minutes. The obtained white precipitate was recrystallized in hot toluene and precipitated with cold methanol.

ESI-MS: $m / z=589[\mathrm{M}+.+1] ; m / z=190\left[\mathrm{~S}_{2} \mathrm{NC}_{8} \mathrm{H}_{16}\right] .1 \mathrm{H}$ NMR $\left(\mathrm{CdCl}_{3}, 400 \mathrm{MHz}\right): \delta \mathrm{ppm} 0.91(\mathrm{~m}, 3 \mathrm{H}), 1.33(\mathrm{~m}, 16 \mathrm{H})$, 1.59 (s, 5H), 2.18 (s, 1H), 3.32 (s, 7H), 3.75 (m, 5H).

Elemental analysis: $\mathrm{C}_{16} \mathrm{H}_{32} \mathrm{~N}_{2} \mathrm{~S}_{4} \mathrm{~Pb}$. Calculated: $\mathrm{C}=32.69$, $\mathrm{H}=5.49, \mathrm{~N}=4.77$, and $\mathrm{S}=21.77$. Observed: $\mathrm{C}=31.96$, $\mathrm{H}=6.27, \mathrm{~N}=4.64$, and $\mathrm{S}=21.54$. Melting point: $88-90^{\circ} \mathrm{C}$. Yield: $94.00 \%$

2.4. Synthesis of $[\mathrm{Pb}((\mathrm{SePiPr}) 2 \mathrm{~N}$ (S2CNHexMe)] Complex. Equimolar quantities of $\left[\mathrm{Pb}\left(\mathrm{S}_{2} \mathrm{CNHexMe}\right)_{2}\right]$ and $\left[\mathrm{Pb}\left(\left(\mathrm{SeP}^{\mathrm{i}} \mathrm{Pr}_{2}\right)_{2} \mathrm{~N}\right)_{2}\right]$ complexes were refluxed in chloroform

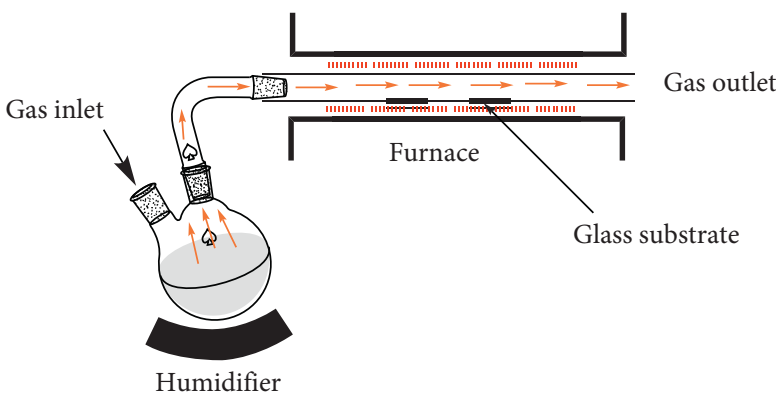

Figure 1: A schematic diagram of the AACVD setup.

for 2 hours and cooled. The cooled solution was then precipitated with excess methanol. The precipitate was filtered under vacuum and dried.

Elemental analysis: $\mathrm{C}_{20} \mathrm{H}_{44} \mathrm{~N}_{2} \mathrm{P}_{2} \mathrm{~S}_{2} \mathrm{Se}_{2} \mathrm{~Pb}$. Calculated: $\mathrm{C}=29.87$, $\mathrm{H}=5.52, \mathrm{~N}=3.59, \mathrm{~S}=7.96, \mathrm{P}=7.71$, and $\mathrm{Pb}=25.79 \%$. Observed: $\mathrm{C}=29.95, \mathrm{H}=5.81, \mathrm{~N}=3.40, \mathrm{~S}=7.09, \mathrm{P}=7.97$, and $\mathrm{Pb}=25.18 \%$. $1 \mathrm{H} \mathrm{NMR}\left(\mathrm{CDCl}_{3}\right)$ : 0.80-0.88 (m, 7H), 1.11-1.35 (m, 21H), 1.59-1.74 (m, 14H), 2.10-2.27 (m, 7H), 3.26-3.35 (m, 5H), 3.67-3.76 (m, 5H); $31 \mathrm{P}\{1 \mathrm{H}\} \mathrm{NMR}\left(\mathrm{CDCl}_{3}\right)$ : $55.41 \mathrm{ppm}$ (satellite peaks $\left.57.13,53.76 \mathrm{ppm}\right)$; 77Se NMR $\left(\mathrm{CDCl}_{3}\right)$ : $-175.57,-183.00 \mathrm{ppm} ; v$ (C-N) $1228 \mathrm{~cm}^{-1}, v$ (C-S) $1026 \mathrm{~cm}^{-1}$. Melting point: $78-80^{\circ} \mathrm{C}$. Yield: $92.00 \%$

2.5. Aerosol-Assisted Chemical Vapour Deposition (AACVD) of Thin Films. The thin films were deposited by the aerosolassisted chemical vapour deposition (AACVD) of $\left[\mathrm{Pb}\left(\left(\mathrm{SeP}^{\mathrm{i}} \mathrm{Pr}_{2}\right)_{2} \mathrm{~N}\right)\left(\mathrm{S}_{2} \mathrm{CNH}\right.\right.$ exMe $\left.)\right]$ complex solution (200 mg in $10 \mathrm{ml}$ tetrahydrofuran) on glass substrates. The depositions were done at $300,350,400$, and $450^{\circ} \mathrm{C}$ for 30 minutes.

2.6. Crystal Structure Refinement. A slow evaporation process was used to obtain single crystals of $\left[\mathrm{Pb}\left(\left(\mathrm{SeP}^{\mathrm{i}} \mathrm{Pr}_{2}\right)_{2} \mathrm{~N}\right.\right.$ $\left.\left(\mathrm{S}_{2} \mathrm{CNHexMe}\right)\right]$ in a 1:2 mixture of chloroform/methanol. The crystal structure was determined with a Bruker Smart Apex diffractometer having a Mo $\mathrm{K} \alpha \mathrm{X}$-ray source and a CCD collector. The structure was calculated using SHELXTL package version 6.10. A full-matrix least-square on F2 was used for the refinement using direct methods. All the hydrogen atoms were allotted isotropic thermal parameters at calculated positions. Anisotropic atomic displacement parameters were used to refine other atoms.

\section{Results and Discussion}

3.1. Crystal Structure of $\left[\mathrm{Pb}\left(\left(\mathrm{SeP}^{i} \mathrm{Pr}_{2}\right)_{2} \mathrm{~N}\right)\left(\mathrm{S}_{2} \mathrm{CNHexMe}\right)\right]$. The structural refinement and crystal data are listed in Table 1. Direct methods were employed to solve the structure. The hydrogen atoms were placed in calculated positions with $\mathrm{C}-\mathrm{H}$ lengths of $0.95(\mathrm{CH}), 0.99\left(\mathrm{CH}_{2}\right)$, and $0.98\left(\mathrm{CH}_{3}\right) \AA$. All the Uiso $(\mathrm{H})$ values were fixed at $1.2 \mathrm{Ueq}$ (C) except for $\mathrm{CH}_{3}$ where it was $1.5 \mathrm{Ueq}(\mathrm{C})$. The nonhydrogen atoms were refined anisotropically.

Figure 2 shows the crystal structure of the complex. The lead atom has a distorted square pyramidal geometry with 2 sulphur and 2 selenium atoms coordinating the central atom at the base of the pyramid and a lone pair occupying the axial position of the 
TABle 1: Crystal structure information for $\mathrm{Pb}$ $\left[\left(\mathrm{SeP}^{\mathrm{i}} \mathrm{Pr}_{2}\right)_{2} \mathrm{~N}\left(\mathrm{~S}_{2} \mathrm{CNHexMe}\right)\right]$.

\begin{tabular}{lc}
\hline Chemical formula & $\mathrm{C}_{20} \mathrm{H}_{44} \mathrm{~N}_{2} \mathrm{P}_{2} \mathrm{~Pb} \mathrm{~S}_{2} \mathrm{Se}_{2}$ \\
\hline Formula wt & 803.74 \\
Cryst syst & Monoclinic \\
Space group & $\mathrm{P} 2(1) / \mathrm{c}$ \\
$a(\AA)$ & $10.1790(2)$ \\
$b(\AA)$ & $18.3729(2)$ \\
$c(\AA)$ & $31.7436(4)$ \\
$\alpha(\mathrm{deg})$ & 90 \\
$\beta(\mathrm{deg})$ & $95.9940(10)$ \\
$\gamma(\mathrm{deg})$ & 90 \\
$V\left(\AA^{3}\right)$ & $5904.16(15)$ \\
$Z$ & 4 \\
$\left.\mathrm{D}_{\text {calcd }}(\mathrm{g} \mathrm{cm})^{-3}\right)$ & 1.808 \\
$\mu(\mathrm{Mo} \mathrm{K} \alpha)\left(\mathrm{mm}^{-1}\right)$ & 16.351 \\
$\mathrm{R} 1(I>2 \sigma(\mathrm{I}))^{\mathrm{b}}$ & 0.0298 \\
wR2 $(\text { all data })_{\mathrm{GOF} \text { on } \mathrm{F}^{2}}$ & 0.0721 \\
\hline
\end{tabular}

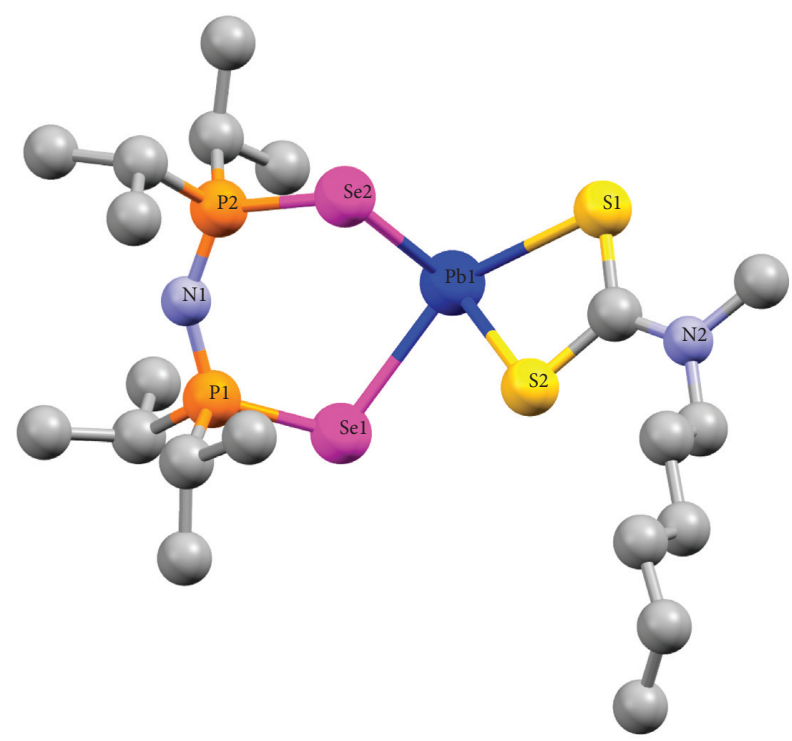

Figure 2: An ORTEP thermal ellipsoid structure of $\left[\mathrm{Pb}\left(\left(\mathrm{SeP}^{\mathrm{i}} \mathrm{Pr}_{2}\right)_{2} \mathrm{~N}\right)\left(\mathrm{S}_{2} \mathrm{CNHexMe}\right)\right]$.CCDC number 1918617 .

lead atom. Each selenium atom is directly bonded to a phosphorus atom just as is found in the $\left[\mathrm{Pb}\left(\left(\mathrm{SeP}^{\mathrm{i}} \mathrm{Pr}_{2}\right)_{2} \mathrm{~N}\right)_{2}\right]$ complex and the sulphur atoms are bonded to the ipso carbon just as is found in the $\left[\mathrm{Pb}\left(\mathrm{S}_{2} \mathrm{CNHexMe}\right)_{2}\right]$ complex. The complex has a monoclinic crystal structure with P2 (1)/c space group.

The bond lengths and bond angles selected are shown in Table 2. The bond lengths for $\mathrm{Pb}-\mathrm{S}$ were found as 2.6707 and $2.9515 \AA$. These are significantly different from each other. It can be inferred from the bond lengths that one $S$ atom forms a stronger bond to the $\mathrm{Pb}$ atom than the other. The structure also indicates that the $\mathrm{Pb}$-Se bond lengths are similar to the $\mathrm{Pb}-\mathrm{S}$. This suggests that the bond strengths of $\mathrm{Pb}-\mathrm{S}$ and $\mathrm{Pb}-\mathrm{Se}$ may not be significantly different from each other. $\mathrm{Pb}$-Se bond lengths in the complex were similar to the $\mathrm{Pb}\left[\left(\mathrm{SeP}^{\mathrm{i}} \mathrm{Pr}_{2}\right)_{2} \mathrm{~N}\right]_{2}$ complex [33].

The average $\mathrm{Se}-\mathrm{Pb}-\mathrm{Se}$ bond angle for the complex is $97.33^{\circ}$ which was close to that of the $\mathrm{Pb}\left[\left(\mathrm{SeP}^{\mathrm{i}} \mathrm{Pr}_{2}\right)_{2} \mathrm{~N}\right]_{2}$
TABLE 2: Selected bond lengths $(\AA)$ and angles $\left({ }^{\circ}\right)$ for the complex.

\begin{tabular}{lc}
\hline $\mathrm{Pb}(1)-\mathrm{S}(2)$ & $2.6707(12)$ \\
$\mathrm{Pb}(1)-\mathrm{Se}(2)$ & $2.8415(5)$ \\
$\mathrm{Pb}(1)-\mathrm{Se}(1)$ & $2.9325(5)$ \\
$\mathrm{Pb}(1)-\mathrm{S}(1)$ & $2.9515(11)$ \\
$\mathrm{Pb}(2)-\mathrm{S}(3)$ & $2.6743(12)$ \\
$\mathrm{Pb}(2)-\mathrm{Se}(3)$ & $2.8411(5)$ \\
$\mathrm{Pb}(2)-\mathrm{Se}(4)$ & $2.9054(5)$ \\
$\mathrm{Pb}(2)-\mathrm{S}(4)$ & $2.9587(11)$ \\
$\mathrm{S}(2)-\mathrm{Pb}(1)-\mathrm{Se}(2)$ & $96.26(3)$ \\
$\mathrm{S}(2)-\mathrm{Pb}(1)-\mathrm{Se}(1)$ & $83.71(3)$ \\
$\mathrm{Se}(2)-\mathrm{Pb}(1)-\mathrm{Se}(1)$ & $97.667(14)$ \\
$\mathrm{S}(2)-\mathrm{Pb}(1)-\mathrm{S}(1)$ & $63.96(3)$ \\
$\mathrm{Se}(2)-\mathrm{Pb}(1)-\mathrm{S}(1)$ & $87.78(2)$ \\
$\mathrm{Se}(1)-\mathrm{Pb}(1)-\mathrm{S}(1)$ & $147.64(3)$ \\
$\mathrm{S}(3)-\mathrm{Pb}(2)-\mathrm{Se}(3)$ & $97.95(3)$ \\
$\mathrm{S}(3)-\mathrm{Pb}(2)-\mathrm{Se}(4)$ & $82.85(3)$ \\
$\mathrm{Se}(3)-\mathrm{Pb}(2)-\mathrm{Se}(4)$ & $96.993(14)$ \\
$\mathrm{S}(3)-\mathrm{Pb}(2)-\mathrm{S}(4)$ & $63.47(3)$ \\
$\mathrm{Se}(3)-\mathrm{Pb}(2)-\mathrm{S}(4)$ & $86.47(2)$ \\
$\mathrm{Se}(4)-\mathrm{Pb}(2)-\mathrm{S}(4)$ & $146.27(3)$
\end{tabular}

complex of $96.05^{\circ}$ [33]. This indicates that the preformed bonds in the parent compounds were not significantly affected by the formation of the new complex.

3.2. Thermogravimetric Analysis. The TGA thermograms of (A) $\mathrm{Pb}\left[\left(\mathrm{SeP}^{\mathrm{i}} \mathrm{Pr}_{2}\right)_{2} \mathrm{~N}\right]_{2}$, (B) $\left[\mathrm{Pb}\left(\left(\mathrm{SeP}^{\mathrm{i}} \mathrm{Pr}_{2}\right)_{2} \mathrm{~N}\right)\left(\mathrm{S}_{2} \mathrm{CNHexMe}\right)\right]$, and $(\mathrm{C}) \mathrm{Pb}\left(\mathrm{S}_{2} \mathrm{CNHexMe}\right)_{2}$ are presented in Figure 3 . The $\mathrm{Pb}$ $\left[\left(\mathrm{SeP}^{\mathrm{i}} \mathrm{Pr}_{2}\right)_{2} \mathrm{~N}_{2}\right]$ and $\mathrm{Pb}\left[\left(\mathrm{S}_{2} \mathrm{CNHexMe}\right)_{2}\right]$ complexes both showed a 1-step decomposition to form stable residues. The $\mathrm{Pb}\left[\left(\mathrm{SeP}^{\mathrm{i}} \mathrm{Pr}_{2}\right)_{2} \mathrm{~N}\right]_{2}$ had a residue of $20.09 \%$ (28.11\% predicted) and $\mathrm{Pb}\left[\left(\mathrm{S}_{2} \mathrm{CNHexMe}\right)_{2}\right]$ had a residue of $41.16 \%(42.74 \%$ predicted). The $\left[\mathrm{Pb}\left(\left(\mathrm{SeP}^{\mathrm{i}} \mathrm{Pr}_{2}\right)_{2} \mathrm{~N}\right)\left(\mathrm{S}_{2} \mathrm{CNH}\right.\right.$ exMe $\left.)\right]$ complex decomposed in a two-step process. The onset and endset temperatures of the first decomposition step were $271.97^{\circ} \mathrm{C}$ and $308.81^{\circ} \mathrm{C}$, respectively. The percentage weight at onset was $99.75 \%$, having lost $0.25 \%$ as volatile substances. The weight loss at the endset of the first decomposition step was $20.38 \%$. This may be due to the loss of the [CNHexMe] fragment and some sulphur gases [34]. The decomposition was slow at the first step with a decomposition temperature of $297.92^{\circ} \mathrm{C}$. There was a weight loss between the first and second decomposition steps of $15.24 \%$. This may result from the thermal instability of the complex between those temperatures. The onset and endset temperatures of the second decomposition step were $367.60^{\circ} \mathrm{C}$ and $382.81^{\circ} \mathrm{C}$, respectively, with a corresponding weight loss of $32.13 \%$. This was due to the loss of the $\left[{ }^{\mathrm{i}} \mathrm{Pr}_{2} \mathrm{PNP}^{\mathrm{i}} \mathrm{Pr}_{2}\right]$ fragment. The decomposition of the second step was fast with a decomposition temperature of $381.53^{\circ} \mathrm{C}$. The residue obtained at $600^{\circ} \mathrm{C}$ was 32.0 while the expected one for $\mathrm{PbSe}_{1-x} \mathrm{~S}_{x}$ was $32.7 \%$. The percentage residue was very close to the expected, indicating the suitability of the complex as a single-source precursor for the production of ternary lead chalcogenide.

3.3. $p X R D$ of Thin Films Deposited from $\left[\mathrm{Pb}\left(\left(\mathrm{SeP}^{i} \mathrm{Pr}_{2}\right)_{2} \mathrm{~N}\right)\left(\mathrm{S}_{2} \mathrm{CNHexMe}\right)\right]$. The pXRD for the thin 


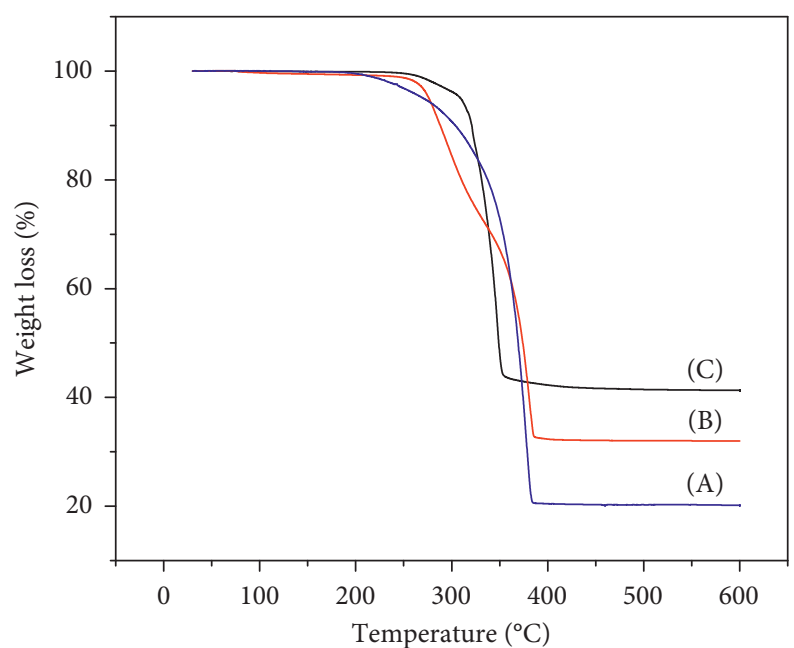

Figure 3: TGA plot of (A) $\mathrm{Pb}\left[\left(\mathrm{SeP}^{\mathrm{i}} \mathrm{Pr}_{2}\right)_{2} \mathrm{~N}\right]_{2}$, (B) $\left[\mathrm{Pb}\left(\left(\mathrm{SeP}^{\mathrm{i}} \mathrm{Pr}_{2}\right)_{2} \mathrm{~N}\right)\left(\mathrm{S}_{2} \mathrm{CNHexMe}\right)\right]$, and $(\mathrm{C}) \mathrm{Pb}\left(\mathrm{S}_{2} \mathrm{CNHexMe}\right)_{2}$.

films deposited mainly matched with standard lead selenide peaks. The results indicate that sulphur is lost in the deposition process. This suggests that the C-S bond is relatively stronger than the $\mathrm{Pb}-\mathrm{S}$ bond. As a result, upon thermal decomposition, there is a breaking of the $\mathrm{Pb}-\mathrm{S}$ bond leading to the formation of the $\left[\mathrm{S}_{2} \mathrm{CNHexMe}\right]$ moiety, which volatilizes in the decomposition process [35]. There was a slight shift of the peaks from the standard PbSe peaks from $300-350^{\circ} \mathrm{C}$ and, in some cases, at $400^{\circ} \mathrm{C}$. Earlier reports on the formation of $\mathrm{PbSe}_{1-x} \mathrm{~S}_{x}$ from SSPs were possible when the mole fraction of the sulphurcontaining complex was greater than $0.5[19,20]$. However, in this experiment, the complex contained equal fractions of sulphur and selenium. Stacked pXRD spectra of the thin films at various temperatures are shown in Figure 4 .

3.4. SEM Micrographs of the Thin Films. The SEM micrographs of thin films deposited at $300^{\circ} \mathrm{C}, 350^{\circ} \mathrm{C}, 400^{\circ} \mathrm{C}$, and $450^{\circ} \mathrm{C}$ (Figure 5) show cubic lead chalcogenide crystals for the deposits at all the temperatures. Generally, as the temperature increased from 300 to $450^{\circ} \mathrm{C}$, the surface coverage of the thin films also increased. During a deposition process, certain properties of the thin films change. For example, the morphology can change depending on a range of factors which include deposition time, temperature, and solvent. For this research, all deposition parameters were constant except for temperature. Therefore, the changes in morphology could be attributed to the changes in temperature. At 300 and $350^{\circ} \mathrm{C}$, the particle sizes decreased from $400 \mathrm{~nm}$ to $200 \mathrm{~nm}$ and further decreased to $150 \mathrm{~nm}$ at $400^{\circ} \mathrm{C}$. There was an increase of particle size to $250 \mathrm{~nm}$ at $450^{\circ} \mathrm{C}$. Although this trend is not normal, as it is expected that particle size increases with increasing temperature, it can be observed

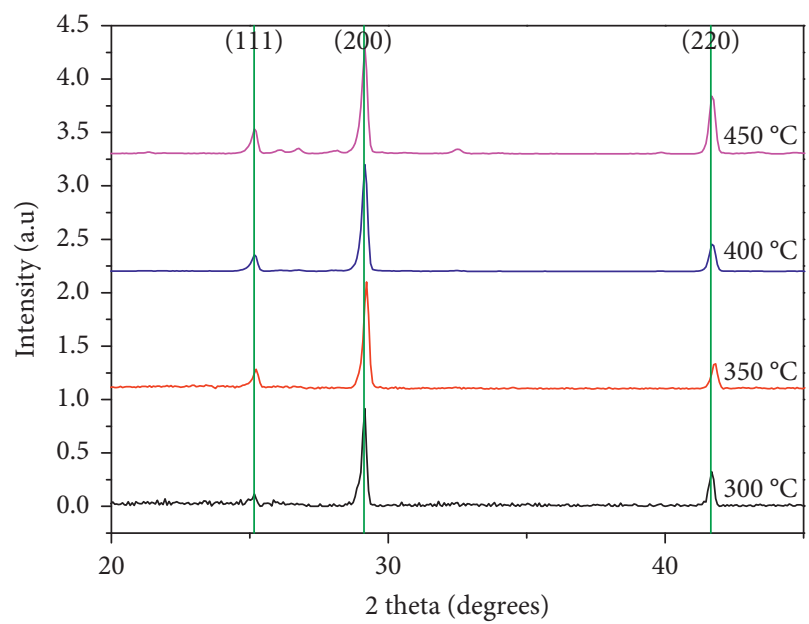

FIGURE 4: A stacked set of four pXRD spectra showing the diffracting pattern of thin films deposited from $\left[\mathrm{Pb}\left(\left(\mathrm{SeP}^{\mathrm{i}} \mathrm{Pr}_{2}\right)_{2} \mathrm{~N}\right.\right.$ $\left(\mathrm{S}_{2} \mathrm{CNH}\right.$ exMe $\left.)\right]$ complex at $300,350,400$, and $450^{\circ} \mathrm{C}$. The green lines are $\mathrm{PbSe}$ matching peaks.

from the SEM micrographs that the particle formation was irregular at the lower temperatures and may have accounted for the irregular particle sizes. The trend, however, became normal at higher temperatures due to agglomeration and formation of regular-sized particles. At $400^{\circ} \mathrm{C}$, there were some truncated cubes which could have formed from the agglomeration of smaller cubes in a nonspecific pattern. The extent of irregularities in the morphology is very prominent at $450^{\circ} \mathrm{C}$. Shapes such as flakes, triangles, truncated cubes, and rectangles were observed in addition to the well-resolved cubes.

The EDAX quantification on the thin films (Figure 6) indicated the formation of $\mathrm{PbSe}(52 \%: 48 \%)$ at all the deposition temperatures. The thin films were lead rich, which is similar to our earlier reports $[24,25,34,36,37]$. 


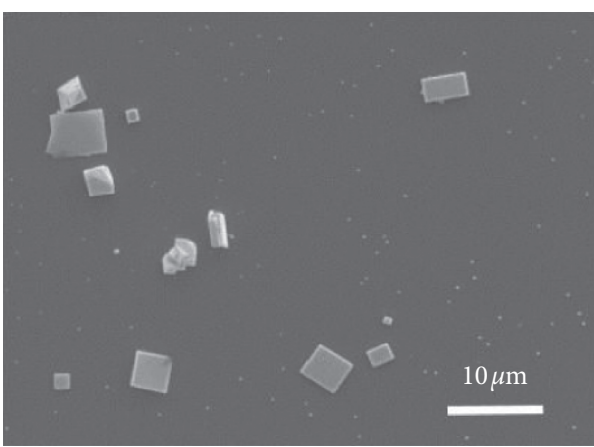

(a)

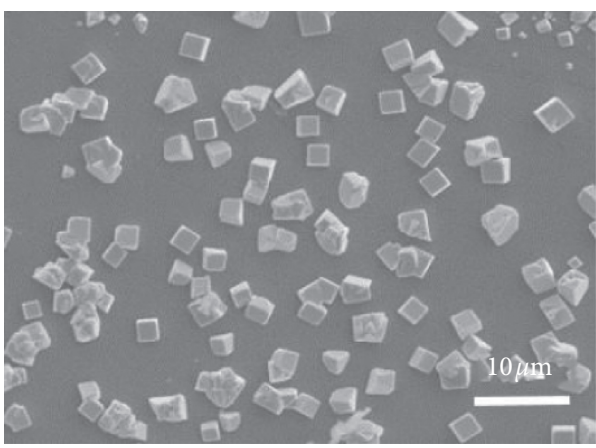

(c)

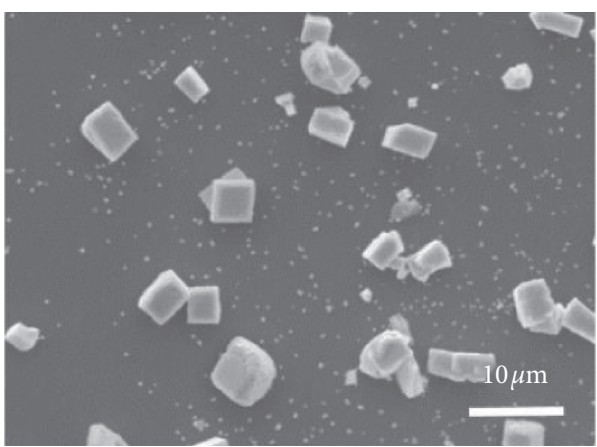

(b)

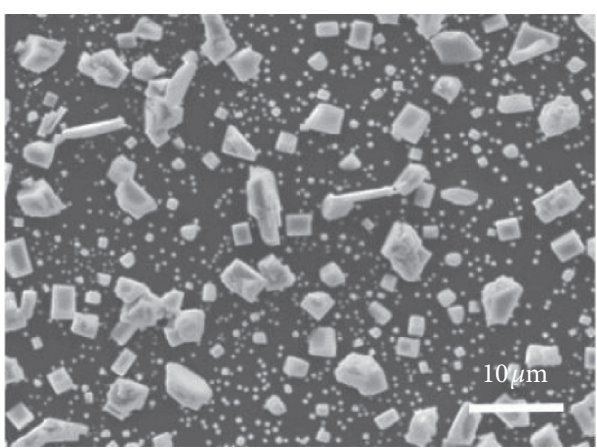

(d)

FiguRE 5: SEM micrographs at 5000x magnification of thin films deposited from $\left[\mathrm{Pb}\left(\left(\mathrm{SeP}^{\mathrm{i}} \mathrm{Pr}_{2}\right)_{2} \mathrm{~N}\left(\mathrm{~S}_{2} \mathrm{CNHexMe}\right)\right)\right]$. (a) $300^{\circ} \mathrm{C},(\mathrm{b}) 350^{\circ} \mathrm{C},(\mathrm{c})$ $400^{\circ} \mathrm{C}$, and (d) $450^{\circ} \mathrm{C}$.

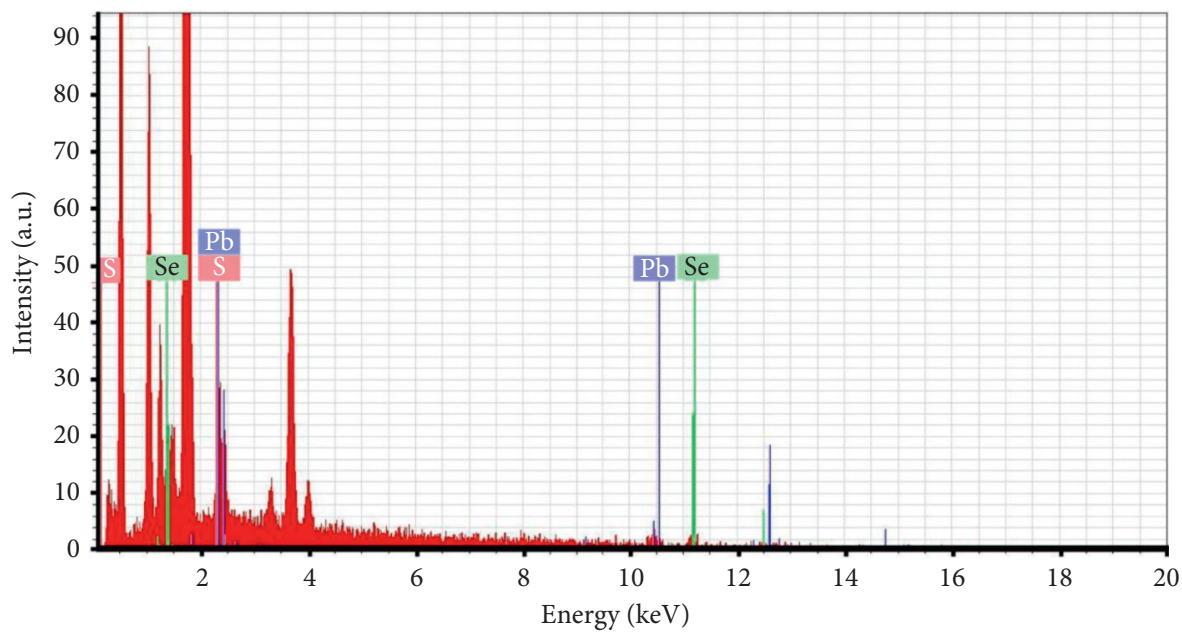

Figure 6: EDAX spectrum of thin films deposited from $\left[\mathrm{Pb}\left(\left(\mathrm{SeP}^{\mathrm{i}} \mathrm{Pr}_{2}\right)_{2} \mathrm{~N}\left(\mathrm{~S}_{2} \mathrm{CNHexMe}\right)\right)\right]$.

\section{Conclusion}

A new complex $\left[\mathrm{Pb}\left(\left(\mathrm{SeP}^{\mathrm{i}} \mathrm{Pr}_{2}\right)_{2} \mathrm{~N}\left(\mathrm{~S}_{2} \mathrm{CNHexMe}\right)\right]\right.$ suitable for making lead chalcogenide nanoparticles and thin films has been successfully synthesised and characterized. The crystal structure of the complex showed a distorted square pyramidal geometry with two sulphur and two selenium atoms forming the base and a lone pair at the axial position of the central atom. The complex was used as a single-source precursor to deposit thin films by AACVD. The thin films deposited were cubic $\mathrm{PbSe}$ at all the deposition temperatures.

\section{Data Availability}

The corresponding author will make the supplementary data available upon request. The crystal structure has been deposited in the Cambridge Crystallographic Database with CCDC number 1918617. 


\section{Conflicts of Interest}

The authors declare that they have no conflicts of interest.

\section{Acknowledgments}

The authors would like to thank the Royal Society-Leverhulme Africa Award grant for their travel support. The authors also acknowledge the immense contribution of Prof. Paul O'Brien, FRS, CBE, to the success of this work.

\section{References}

[1] N. O. Boadi, M. A. Malik, P. O'Brien, and J. A. M. Awudza, "Single source molecular precursor routes to lead chalcogenides," Dalton Transactions, vol. 41, pp. 10497-10506, 2012.

[2] J. Gan and L. Qiao, "Colloidal quantum dots for highly efficient photovoltaics," in Quantum Dot Optoelectronic Devices, pp. 49-82, Springer, Berlin, Germany, 2020.

[3] J. Liu and J. Zhang, "Nanointerface chemistry: lattice-mismatch-directed synthesis and application of hybrid nanocrystals," Chemical Reviews, vol. 120, no. 4, pp. 2123-2170, 2020.

[4] W. Ma, J. M. Luther, H. Zheng, Y. Wu, and A. P. Alivisatos, "Photovoltaic devices employing ternary PbSxSe1-xNanocrystals," Nano Letters, vol. 9, no. 4, pp. 1699-1703, 2009.

[5] Y. Ma, Y. Zhang, and W. W. Yu, "Near infrared emitting quantum dots: synthesis, luminescence properties and applications," Journal of Materials Chemistry C, vol. 7, no. 44, pp. 13662-13679, 2019.

[6] S. Gwo, H.-Y. Chen, M.-H. Lin, L. Sun, and X. Li, "Nanomanipulation and controlled self-assembly of metal nanoparticles and nanocrystals for plasmonics," Chemical Society Reviews, vol. 45, no. 20, pp. 5672-5716, 2016.

[7] S. V. Kershaw, L. Jing, X. Huang, M. Gao, and A. L. Rogach, "Materials aspects of semiconductor nanocrystals for optoelectronic applications," Materials Horizons, vol. 4, no. 2, pp. 155-205, 2017.

[8] A. Khare, "A critical review on the efficiency improvement of upconversion assisted solar cells," Journal of Alloys and Compounds, vol. 821, p. 153214, 2020.

[9] U. R. Kortshagen, R. M. Sankaran, R. N. Pereira, S. L. Girshick, J. J. Wu, and E. S. Aydil, "Nonthermal plasma synthesis of nanocrystals: fundamental principles, materials, and applications," Chemical Reviews, vol. 116, no. 18, pp. 11061-11127, 2016.

[10] H. Lee, H.-J. Song, M. Shim, and C. Lee, "Towards the commercialization of colloidal quantum dot solar cells: perspectives on device structures and manufacturing," Energy \& Environmental Science, vol. 13, no. 2, pp. 404-431, 2020.

[11] Z. L. Teh, L. Hu, Z. Zhang et al., "Enhanced power conversion efficiency via hybrid ligand exchange treatment of p-type PbS quantum dots," ACS Applied Materials \& Interfaces, vol. 12, no. 20, pp. 22751-22759, 2020.

[12] H. W. Hillhouse and M. C. Beard, "Solar cells from colloidal nanocrystals: fundamentals, materials, devices, and economics," Current Opinion in Colloid \& Interface Science, vol. 14, no. 4, pp. 245-259, 2009.

[13] A. H. Khan, R. Brescia, A. Polovitsyn, I. Angeloni, B. MartínGarcía, and I. Moreels, "Near-Infrared emitting colloidal PbS nanoplatelets: lateral size control and optical spectroscopy," Chemistry of Materials, vol. 29, no. 7, pp. 2883-2889, 2017.
[14] J. M. Luther, M. Law, M. C. Beard et al., "Schottky solar cells based on colloidal nanocrystal films," Nano Letters, vol. 8, no. 10, pp. 3488-3492, 2008.

[15] I. Moreels, K. Lambert, D. De Muynck et al., "Composition and size-dependent extinction coefficient of colloidal PbSe quantum dots," Chemistry of Materials, vol. 19, no. 25, pp. 6101-6106, 2007.

[16] G. Zhai, C. P. Church, A. J. Breeze, D. Zhang, G. B. Alers, and S. A. Carter, "Quantum dot PbS0.9Se0.1/TiO2heterojunction solar cells,” Nanotechnology, vol. 23, no. 40, p. 405401, 2012.

[17] B. Gao, M. Zhao, Q. Wang, K.-B. Kang, Z.-G. Xu, and H.-L. Zhang, "Improved synthesis of PbSxSe1-x ternary alloy nanocrystals and their nonlinear optical properties," New Journal of Chemistry, vol. 37, no. 6, pp. 1692-1695, 2013.

[18] M. Brumer, A. Kigel, L. Amirav et al., "PbSe/PbS and PbSe/ PbSexS1-x core/shell nanocrystals," Advanced Functional Materials, vol. 15, no. 7, pp. 1111-1116, 2005.

[19] S. A. Saah, P. D. Mcnaughter, M. A. Malik, J. A. M. Awudza, N. Revaprasadu, and P. O’Brien, "PbS x Se $1-x$ thin films from the thermal decomposition of lead (II) dodecylxanthate and bis (N, N-diethyl-N'-naphthoylselenoureato) lead (II) precursors," Journal of Materials Science, vol. 53, no. 6, pp. 4283-4293, 2017.

[20] S. A. Saah, M. D. Khan, P. D. McNaughter, J. A. M. Awudza, N. Revaprasadu, and P. O'Brien, "Facile synthesis of a $\mathrm{PbS1-xSex}(0 \leq x \leq 1)$ solid solution using bis (N, N-diethyl$\mathrm{N}^{\prime}$-naphthoylchalcogenoureato) lead (II) complexes," New Journal of Chemistry, vol. 42, no. 20, pp. 16602-16607, 2018.

[21] K. Ahmad, M. Afzaal, P. O’Brien, G. Hua, and J. Derek Woollins, "Morphological evolution of PbSe crystals via the CVD route," Chemistry of Materials, vol. 22, no. 16, pp. 4619-4624, 2010.

[22] J. Akhtar, M. A. Malik, S. K. Stubbs, P. O’Brien, M. Helliwell, and D. J. Binks, "Morphology-tailored synthesis of $\mathrm{PbSe}$ nanocrystals and thin films from bis $\left[\mathrm{N}, \mathrm{N}\right.$-diisobutyl-N ${ }^{\prime}-(4-$ nitrobenzoyl) selenoureato]lead (II)," European Journal of Inorganic Chemistry, vol. 2011, no. 19, pp. 2984-2990, 2011.

[23] A. Bhardwaj, P. Srivastava, and H. K. Sehgal, "Chemically deposited PbSe nanoparticle films," Journal of The Electrochemical Society, vol. 154, no. 10, p. K83, 2007.

[24] N. O. Boadi, P. D. McNaughter, M. Helliwell, M. A. Malik, J. A. M. Awudza, and P. O’Brien, “The deposition of PbS and $\mathrm{PbSe}$ thin films from lead dichalcogenoimidophosphinates by AACVD," Inorganica Chimica Acta, vol. 453, pp. 439-442, 2016.

[25] N. O. Boadi, S. A. Saah, M. Helliwell, and J. A. M. Awudza, "Hot-injection synthesis of $\mathrm{PbE}(\mathrm{E}=\mathrm{S}, \mathrm{Se})$ nanoparticles from dichalcogenoimidophosphinato lead (II) complexes," ChemistrySelect, vol. 4, no. 47, pp. 13908-13911, 2019.

[26] E. A. Lewis, P. D. McNaughter, Z. Yin et al., "In situ synthesis of $\mathrm{PbS}$ nanocrystals in polymer thin films from lead (II) xanthate and dithiocarbamate complexes: evidence for size and morphology control," Chemistry of Materials, vol. 27, no. 6, pp. 2127-2136, 2015.

[27] S. A. Saah, N. O. Boadi, and C. Wilkins, "Lead ethyl dithiocarbamates: efficient single-source precursors to $\mathrm{PbS}$ nanocubes," Royal Society Open Science, vol. 6, pp. 1-8, 2019.

[28] S. A. Saah, N. O. Boadi, and C. Wilkins, "Deposition of PbS thin films from lead hexadecyl and octadecyl xanthate complexes using the spin coating method," MRS Advances, vol. 4, no. 11-12, pp. 733-742, 2019.

[29] J. Akhtar, M. Afzaal, M. Banski et al., "Controlled synthesis of tuned bandgap nanodimensional alloys of PbSxSe1-x," 
Journal of the American Chemical Society, vol. 133, no. 14, pp. 5602-5609, 2011.

[30] D. Aldakov, A. Lefrançois, and P. Reiss, "Ternary and quaternary metal chalcogenide nanocrystals: synthesis, properties and applications," Journal of Materials Chemistry C, vol. 1, no. 24, pp. 3756-3776, 2013.

[31] C. Piccirillo, R. Binions, and I. P. Parkin, "Synthesis and characterisation of $\mathrm{W}$-doped $\mathrm{VO} 2$ by aerosol assisted chemical vapour deposition," Thin Solid Films, vol. 516, no. 8, pp. 1992-1997, 2008.

[32] D. Cupertino, D. J. Birdsall, A. M. Z. Slawin, and J. D. Woollins, "The preparation and coordination chemistry of ${ }^{\mathrm{i}} \mathrm{Pr}_{2} \mathrm{P}(\mathrm{E}) \mathrm{NHP}\left(\mathrm{E}^{\prime}\right) \mathrm{iPr}_{2}\left(\mathrm{E}, \mathrm{E}^{\prime}=\mathrm{Se} ; \mathrm{E}=\mathrm{Se}, \mathrm{E}^{\prime}=\mathrm{S} ; \mathrm{E}=\mathrm{S}, \mathrm{E}^{\prime}=\mathrm{O}\right.$; E, $\mathrm{E}^{\prime}=$ O," Inorganica Chimica Acta, vol. 290, pp. 1-7, 1999.

[33] J. S. Ritch, T. Chivers, K. Ahmad, M. Afzaal, and P. O’Brien, "Synthesis, structures, and multinuclear NMR spectra of tin (II) and lead (II) complexes of tellurium-containing imidodiphosphinate ligands: preparation of two morphologies of phase-pure $\mathrm{PbTe}$ from a single-source precursor," Inorganic Chemistry, vol. 49, no. 3, pp. 1198-1205, 2010.

[34] N. O. Boadi, S. A. Saah, and J. A. M. Awudza, "Synthesis of a novel single-source precursor for the production of lead chalcogenide thin films," Journal of Chemistry, vol. 2020, Article ID 8349549, 7 pages, 2020.

[35] J. Akhtar, M. Afzaal, M. A. Vincent et al., "Understanding the decomposition pathways of mixed sulfur/selenium lead phosphinato complexes explaining the formation of lead selenide," The Journal of Physical Chemistry C, vol. 115, pp. 16904-16909, 2011.

[36] F. G. Hone, F. K. Ampong, T. Abza et al., "The effect of deposition time on the structural, morphological and optical band gap of lead selenide thin films synthesized by chemical bath deposition method," Materials Letters, vol. 155, pp. 5861, 2015.

[37] A. C. Onicha, N. Petchsang, T. H. Kosel, and M. Kuno, "Controlled synthesis of compositionally tunable ternary PbSexS1-xas well as binary PbSe and PbS nanowires," ACS Nano, vol. 6, no. 3, pp. 2833-2843, 2012. 